\title{
Gene-Based Markers for the Tomato Yellow Leaf Curl Virus Resistance Gene Ty-3
}

\author{
Panpan Dong ${ }^{1,3}$, Koeun Han ${ }^{1}$, Muhammad Irfan Siddique ${ }^{1}$, Jin-Kyung Kwon', Meiai Zhao ${ }^{2}$, Fu Wang ${ }^{3}$, \\ Byoung-Cheorl Kang ${ }^{1}$ * \\ ${ }^{1}$ Department of Plant Science, Plant Genomics and Breeding Institute, and Vegetable Breeding Research Center, College of \\ Agriculture and Life Sciences, Seoul National University, Seoul 08826, Korea \\ ${ }^{2}$ College of Life Science, Qingdao Agricultural University, Qingdao 266-109, China \\ ${ }^{3}$ College of Horticulture, Qingdao Agricultural University, Qingdao 266-109, China
}

\begin{abstract}
The viral disease induced by Tomato yellow leaf curl virus (TYLCV) reduces tomato (Solanum lycopersicum) yield significantly in tropical and subtropical regions. A number of loci, including $T y-1$ to $T y-5$, conferring resistance to TYLCV have been described and introgressed into modern tomato cultivars. The availability of molecular markers linked to these genes would expedite the introgression of TYLCV resistance into commercial cultivars. In the present study, we developed gene-based markers linked to the Ty-3 gene using a segregating population derived from a cross between the TYLCV-resistant line S. lycopersicum 'A45' and the susceptible line S. lycopersicum 'A39'. Agrobacterium-mediated screening was used to test TYLCV resistance of plants in the segregating population, and the resistance was evaluated by a visual scoring method and polymerase chain reaction analysis. By comparing sequences of the $T y$-3 genes of the resistant and susceptible lines, two high-resolution melting (HRM) markers (Ty3-HRM1 and Ty3-HRM2) and one sequence characterized amplified region (SCAR) marker (Ty3-SCAR1) were developed. The HRM markers were based on single nucleotide polymorphisms at the 13th exon and the 15th intron, whereas the SCAR marker was based on a 246-bp deletion in the 16th intron. These gene-based markers will be useful tools for marker-assisted selection in breeding programs to improve TYLCV resistance of tomato.
\end{abstract}

Keywords TYLCV, Gene-specific makers, SCAR, High-resolution melting

\section{INTRODUCTION}

Tomato (Solanum lycopersicum) belongs to the Solanaceae family and is one of the most important cultivated vegetables worldwide. Since it has high nutrititional value, tomato has become a popular vegetable grown in large scale (Naika et al. 2005). Tomato yellow leaf curl virus (TYLCV) disease transmitted by the whitefly (Bemisia tabaci) is one of the most devastating diseases causing quality and yield reduction in tomato (Liu et al. 2013). According to recent reports, TYLCV disease is spreading due to global warming, with current outbreaks in the United States and China (Rojas et al. 2007; Zhang et al. 2009; Melzer et al. 2010). Recently, TYLCV incidence was also reported in Korea (Lee et al. 2010). TYLCV is a pathogen with broad host range, including tomato $(S$. lycopersicum), potato (S. tuberosum), pepper (Capsicum annuиm), tobacco (Nicotiana tabacum), and several other dicot species (Polston and Anderson 1997). Leaf curling, yellowing and plant stunting are typical disease symptoms in infected plants (Ji et al. 2009a). If plants are attacked by TYLCV at the juvenile stage, up to $100 \%$ yield losses can occur (Varma and Malathi 2003). Disease management for TYLCV has focused on whitefly control, and these practices are uneconomical and laborious as well as including periodical application of insecticide (Hilje et al. 2001; Palumbo et al. 2001). Furthermore, insecticide resistance in whitefly has been described (Horowitz et al. 2007), highlighting the urgent need for alternative approaches to TYLCV disease management, such as the

Received January 12, 2016; Revised February 11, 2016; Accepted February 11, 2016; Published February 28, 2016

*Corresponding author Byoung-Cheorl Kang, bk54@snu.ac.kr, Tel: +82-2-880-4563, Fax: +82-2-873-2056 
development of resistant cultivars (Verlaan et al. 2013).

To speed up the process of introgression of disease resistance genes to elite breeding materials, molecular markers have been developed and utilized in major crop plants. Accordingly, molecular markers have become essential tools for marker-assisted selection in breeding programs, including those aimed to improve resistance to TYLCV, and also for map-based cloning to isolate the genes controlling traits (Gonzalez-Cabezuelo and Lozano 2012). Most tomato cultivars are susceptible to TYLCV; however, several resistance sources have been identified in wild tomato species, such as $S$. pimpinellifolium, S. chilense, S. peruvianum, S. habrochaites, and S. cheesmaniae (Ji et al. 2007; Verlaan et al. 2013). TYLCV resistance sources include $T y-1, T y-2, T y-3, T y-4$, and $T y-5$, and the genes underlying $T y-1$ and $T y-3$ have been identified (Verlaan et al. 2013). The Ty- 1 locus in S. chilense LA1969 is linked with the $T y-3$ locus on tomato chromosome 6 (Ji et al. 2007). $T y-1$ was first mapped to the interval between markers T0774 and SL_2.40ch06_30.891, and Ty-3 was mapped between the markers UF_TY3_P1 and UF_TY3_P23 in a recombinant inbred line carrying S. chilense LA2779 introgression; ultimately, it was found that $T y-1$ and $T y-3$ are alleles of the same gene (Verlaan et al. 2013). The $T y-1 / T y$-3 gene encodes a DFDGD-class RNA-dependent RNA polymerase.

Even though $T y-3$ and $T y-1$ are allelic, $T y-3$ behaves differently than other TYLCV resistance genes. $T y-3$ is effective against TYLCV and the bipartite begomovirus ToMoV (Agrama and Scott 2006). Ty-1 and $T y-2$ genes express incomplete or nearly complete dominance pattern (Ji et al. 2009b). By contrast, Ty-3 has been reported to have an additive effect, and it is a major locus explaining a high proportion of resistance (Ji et al. 2009b). Gene-based molecular markers of $T y-3$ would be useful to predict the phenotypic variations. There have been gene-based markers developed for $T y-1 / T y-3$ by comparative analysis of tomato accessions (Jung et al. 2015; Lee et al. 2015). In the present study, we developed $T y$-3 gene-based co-dominant markers in a bi-parental population to improve the efficiency of genotyping and to increase the diversity of molecular markers.

\section{MATERIALS AND METHODS}

\section{Plant materials}

The accessions used in this genetic analysis were kindly provided by Prof. Wang Fu (College of Horticulture, Qingdao Agricultural University, China). The $\mathrm{F}_{1}$ progeny were produced by crossing a susceptible line $S$. lycopersicum 'A39' and a resistant line S. lycopersicum 'A45' containing $T y-3$, and $\mathrm{F}_{1}$ plants were self-pollinated to construct a segregating population of $150 \mathrm{~F}_{2}$ plants. In addition, $\mathrm{F}_{1}$ was backcrossed to the susceptible line $S$. lycopersicum 'A39', and $75 \mathrm{BC}_{1} \mathrm{~F}_{1}$ plants were produced for genetic analysis. The segregating populations were tested to validate the developed molecular markers.

\section{Virus inoculation and phenotype evaluation}

Agrobacterium cells containing the TYLCV genome (GV3101 pCAMBIA0390_Ty-1.9mer) were provided by Professor Young-Su Seo (Pusan University, Korea). A 5-ml culture of the Agrobacterium cell stock was grown overnight at $30^{\circ} \mathrm{C}$ in LB medium containing kanamycin (50 $\mathrm{mg} / \mathrm{ml})$ and gentamycin $(50 \mathrm{mg} / \mathrm{ml})$. The culture was transferred to a 2-ml tube and centrifuged at 35,000 $\mathrm{g}$ for 2 minutes. The pelleted cells were re-suspended in infiltration buffer $(200 \mu \mathrm{M}$ acetosyringone, $10 \mathrm{mM} \mathrm{MgCl}, 10$ $\mathrm{mM}$ 2-(N-morpholino) ethanesulfonic acid) to a final optical density at $600 \mathrm{~nm}$ (OD600) of 0.3. The suspension was incubated on a rocker for 3 hours at room temperature. Agro-infiltration using a 1-ml needleless syringe was performed on cotyledons of tomato seedlings at the 1-2 true leaf stage. The inoculated plants were placed in a growth chamber at $25^{\circ} \mathrm{C}$ to $28^{\circ} \mathrm{C}$. Disease response was scored at 21 and 28 days post inoculation (dpi) according to the Lapidot scale (Lapidot et al. 2006). Plants with phenotypes scored 0 to 1 were marked as resistant, whereas those scored 2 to 4 were considered susceptible. To confirm the phenotype, DNA was extracted from infected leaves and polymerase chain reaction (PCR) was performed to detect TYLCV (Deng et al. 1994).

\section{DNA extraction}

Fresh leaves of plants were sampled before and after infiltration with TYLCV. DNA was extracted from young 
leaves using the cetyltrimethylammonium bromide protocol (Doyle and Doyle 1987). DNA was dissolved in $1 \times \mathrm{TE}$ buffer, separated by electrophoresis through $1 \%$ agarose gels in $1 \times$ tris-acetate ethylenediaminetetraacetic acid buffer, and quality was tested by staining with ethidium bromide and visualization under the ultraviolet light.

\section{Sequencing the $T y$-3 gene and marker development}

According to previous reports, Solyc06g051170, Solyc06g051180, and Solyc06g051190 are part of the same gene (Verlaan et al. 2013), collectively coding for Ty-3. Three primer sets including Soylc06-18 (F: 5'-GGTTTGAGTCCATTGGAACCT-3', R: 5'-TTCTGCTTTTGAAAAATCTTTGG-3'), Soylc06-19-2 (F: 5'-CAACGGAGGGAGCATATCAT-3', R: 5'-TCTCCCAGGGCTCTCTGTAA-3'), and Solyc06-19-3 (F: 5'-ATCCCCTCAAATTGCTGATG-3', R: 5'-ATGATATGCTCCCTCCGTTG-3') were used to amplify those genes. PCR was performed in a total volume of $50 \mu \mathrm{l}$ containing $10 \times \mathrm{PCR}$ reaction buffer, $0.1 \mathrm{mM}$ deoxy-nucleotide tri-phosphate (dNTP), 0.2 U Taq DNA polymerase, 10 pmol each primer, and $20 \mathrm{ng}$ genomic DNA. PCR conditions were as follows: initial denaturation for 4 minutes at $95^{\circ} \mathrm{C}$ followed by 35 cycles of 30 seconds at $95^{\circ} \mathrm{C}, 30$ seconds at $55^{\circ} \mathrm{C}$, and a final extension of 10 minutes at $72^{\circ} \mathrm{C}$. The digested products were separated on $1 \%$ agarose gels. After gel electrophoresis, DNA was recovered using Zymoclean ${ }^{\mathrm{TM}}$ Gel DNA Recovery Kit (Zymo Research, Irvine, CA, USA) and sequencing was performed at National Instrumentation Center for Environmental Management (Seoul, Korea).

\section{Development of molecular markers for the $T y-3$ gene}

Primers for the sequence-characterized amplified region (SCAR) marker were developed to amplify the region including the deletion in the susceptible line (Table 1). PCR was performed in a total volume of $25 \mu \mathrm{l}$ containing $10 \times$ PCR reaction buffer, $0.25 \mathrm{mM}$ dNTP, $0.2 \mathrm{U}$ Taq DNA polymerase, 10 pmol each primer, and $20 \mathrm{ng}$ genomic DNA. PCR conditions were the same as for sequencing (above). PCR products were separated in 1\% agarose gels.

Single nucleotide polymorphism (SNP) was detected using the high-resolution melting (HRM) method. HRM was carried out in $20-\mu \mathrm{l}$ reaction mixtures containing $10 \times \mathrm{PCR}$ reaction buffer, $0.25 \mathrm{mM}$ each $\mathrm{dNTP}, 5$ pmol each primer, $0.2 \mathrm{U}$ Taq polymerase, $1.25 \mu \mathrm{M}$ Syto9 (Invitrogen, Carlsbad, CA, USA), and 20 ng gDNA, using a Rotor-Gene $^{\mathrm{TM}} 6000$ thermo cycler (Corbett; QIAGEN, Victoria, Australia). Cycling conditions were $95^{\circ} \mathrm{C}$ for 4 minutes, followed by 40 cycles of $95^{\circ} \mathrm{C}$ for 20 seconds, $58^{\circ} \mathrm{C}$ for 20 seconds, and $72^{\circ} \mathrm{C}$ for 30 seconds, and HRM was analyzed for every increment of $0.1^{\circ} \mathrm{C}$ between $70^{\circ} \mathrm{C}$ and $90^{\circ} \mathrm{C}$.

\section{RESULTS}

\section{Evaluation of TYLCV resistance}

The two parental lines of $S$. lycopersicum 'A39' and 'A45', as well as their $\mathrm{F}_{1}, \mathrm{~F}_{2}$, and $\mathrm{BC}_{1} \mathrm{~F}_{1}$ progenies were evaluated for TYLCV resistance using leaf agro-infiltration. Typical disease symptoms of upward leaf curling were observed 1 week after virus infiltration. Resistance or susceptibility of plants was determined via visual evaluation 3 and 4 weeks post infiltration. The resistant parental line ' $\mathrm{A} 45$ ' and $\mathrm{F}_{1}$ plants showed no or very slight virus disease symptoms (Table 2), with disease scores of 0 or 1. The susceptible parental line 'A39' displayed severe TYLCV symptoms corresponding to disease score level 4;

Table 1. Primer sequences for high-resolution melting (HRM) and the sequence-characterized amplified region (SCAR) analysis.

\begin{tabular}{cllc}
\hline \hline Marker & \multicolumn{1}{c}{ Sequence $\left(5^{\prime}{ }^{\prime} 3^{\prime}\right)$} & Type & Product size $(\mathrm{bp})$ \\
\hline Ty3-HRM1 & $\begin{array}{l}\text { TATACGAGGTTCGCCGTCTT } \\
\text { TCTTGATTCTGTCACCATTGAAA }\end{array}$ & HRM & 190 \\
Ty3-HRM2 & $\begin{array}{l}\text { GAATAATGTCAAACCAAGAACTAGGA } \\
\text { TGTTTTCAGTTTAAGAGATTTAGCA }\end{array}$ & HRM & 152 \\
Ty3-SCAR1 & $\begin{array}{l}\text { GCTCAGCATCACCTGAGACA } \\
\text { TGCAGGAACAGAATGATAGAAAA }\end{array}$ & SCAR & 519 (R)/269 (S) \\
\hline
\end{tabular}


112 and $38 \mathrm{~F}_{2}$ plants exhibited resistant and susceptible phenotypes, respectively. To confirm the phenotypes, PCR was performed using primers to amplify the TYLCV DNA. Resistance and susceptibility to TYLCV could be clearly distinguished by the amount of PCR product. For instance, a large amount of PCR amplicon was obtained from the susceptible parent and $F_{2}$ plants, whereas very little or no PCR amplicon was obtained from the resistant parent, $\mathrm{F}_{1}$ plants, and resistant $F_{2}$ plants (Fig. 1). Based on the phenotype evaluation and PCR analysis, the observed phenotype ratio of resistance to susceptibility in the $F_{2}$ population fit to an expected 3:1 ratio (Table 2), confirming that a single dominant gene is responsible for the TYLCV resistance. Consistent with this observation, $\mathrm{BC}_{1} \mathrm{~F}_{1}$ progeny from the same parents comprised 41 resistant and 34 susceptible plants, verifying a 1:1 segregation ratio
(Table 2).

\section{Development of HRM-based markers}

Three SNPs between susceptible and resistant lines were detected in the $T y-3$ gene. One SNP was located in 13th exon, and the other two SNPs were located in the 15th intron region (Fig. 2A). For the first SNP, HRM marker Ty3-HRM1 was designed to amplify $190 \mathrm{bp}$; the other HRM marker Ty3-HRM2 amplified 152 bp and included the other two SNPs (Table 1, Fig. 2B, C). Both HRM markers could discriminate three genotypes (homozygous resistant, heterozygous resistant, and homozygous susceptible) based on different melting curves (Fig. 3A, B). When the developed HRM markers were tested by screening $\mathrm{F}_{2}$ and $\mathrm{BC}_{1} \mathrm{~F}_{1}$ individuals, the results revealed high accuracy, with a clear correlation between genotype and phenotype

Table 2. Segregation for resistance to Tomato yellow leaf curl virus in different populations.

\begin{tabular}{|c|c|c|c|c|c|}
\hline \multirow{2}{*}{ Population } & \multirow{2}{*}{ Expected ratio of $\mathrm{R}: \mathrm{S}$} & \multicolumn{2}{|c|}{ Observed number of plants ${ }^{\mathrm{z}}$} & \multirow{2}{*}{$\chi^{2}$} & \multirow{2}{*}{$P$-value } \\
\hline & & $\mathrm{R}$ & $\mathrm{S}$ & & \\
\hline$P_{1}$ ('A39') & $0: 1$ & 0 & 15 & - & - \\
\hline $\mathrm{P}_{2}$ ('A45’) & $1: 0$ & 15 & 0 & - & - \\
\hline $\mathrm{F}_{1}$ & $1: 0$ & 15 & 0 & - & - \\
\hline $\mathrm{BC}_{1} \mathrm{~F}_{1}$ & $1: 1$ & 41 & 34 & 0.66 & 0.42 \\
\hline $\mathrm{F}_{2}$ & $3: 1$ & 112 & 38 & 0.01 & 0.92 \\
\hline
\end{tabular}

${ }^{\mathrm{z})} \mathrm{R}$ : resistant, S: susceptible.
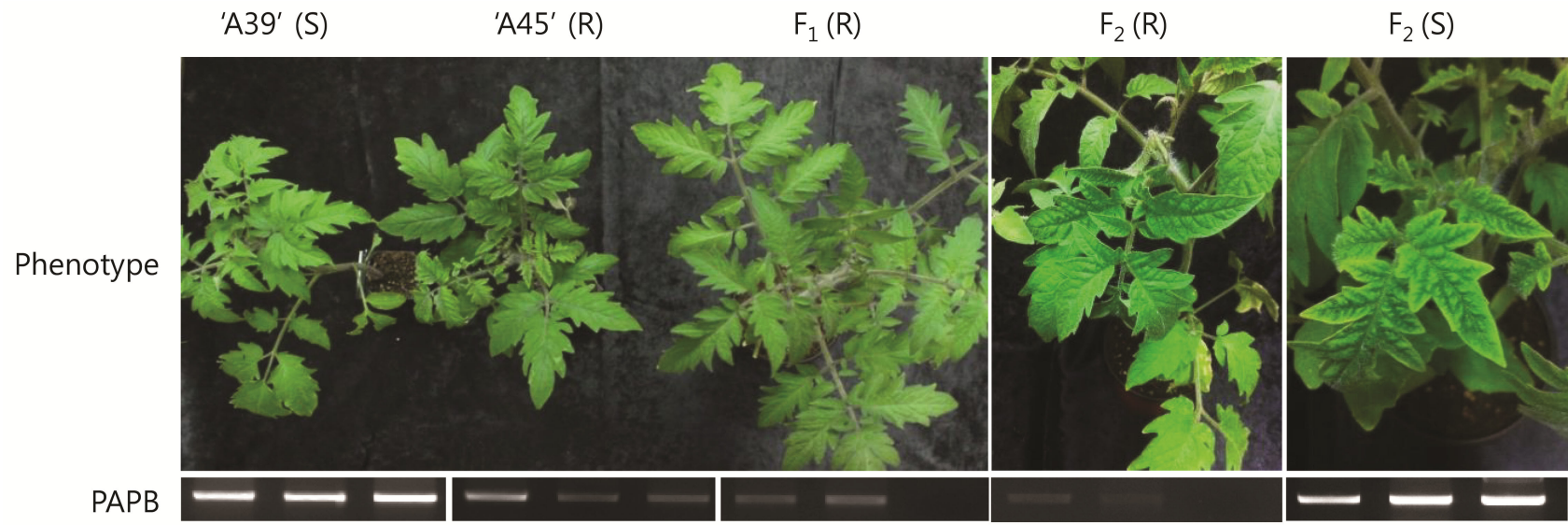

Fig. 1. Phenotype of agro-infiltrated plants. Phenotype of susceptible line 'A39', resistant line 'A45', their $F_{1}$, and $F_{2}$ plants 3 weeks after inoculation are shown. Below: Tomato yellow leaf curl virus DNA was amplified using PAPB marker (Deng et al. 1994).

S: susceptible, R: resistant. 
A

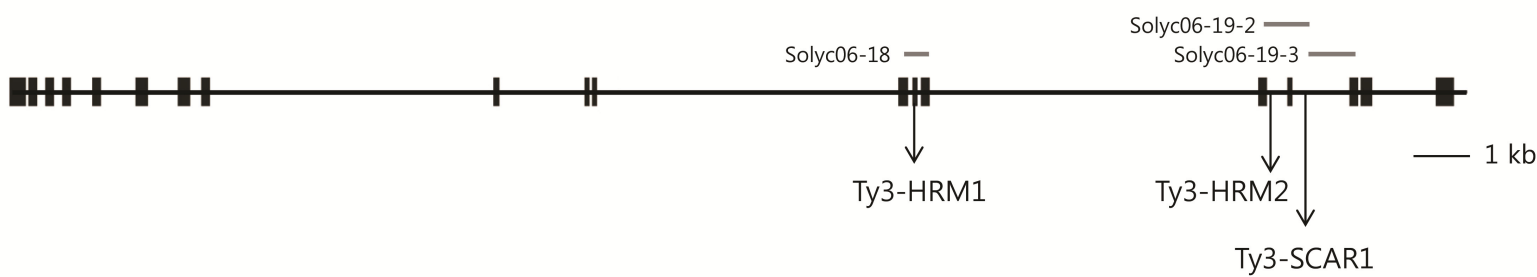

B

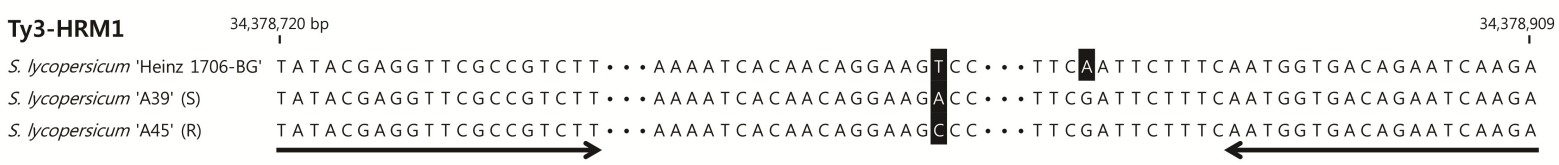

C Tyз-HRM2

$34,385,841$ bp

$34,385,991 \mathrm{bp}$

S. Iycopersicum 'Heinz 1706-BG' G A A T A A T G T C A A A C C A A G A A C T A G G A • . - G T

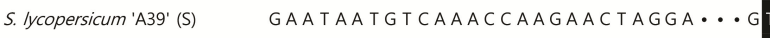

S. Iycopersicum 'A45' (R)

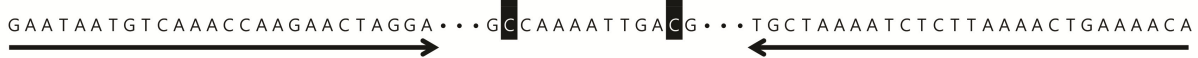

A A A A T TGATG

AAAATTGAT

D

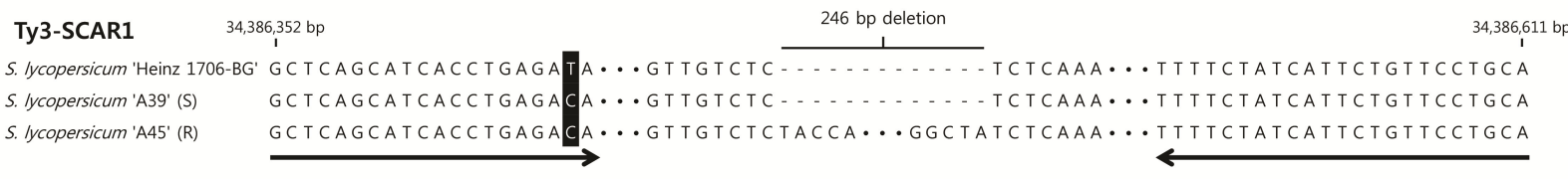

Fig. 2. Physical locations and sequences of molecular markers developed based on the $T y-3$ gene. Genetic structure of Ty-3 gene (A), modified from Verlaan et al. (2013). Genetic sequences of tomato reference genome SL2.50 (Heinz 1706-BG), susceptible line (A39), and resistant line (A45) were aligned. Primer locations of Ty3-HRM1 (B), Ty3-HRM2 (C), and Ty3-SCAR1 (D) are shown as arrows.

HRM: high-resolution melting, SCAR: sequence-characterized amplified region.

A

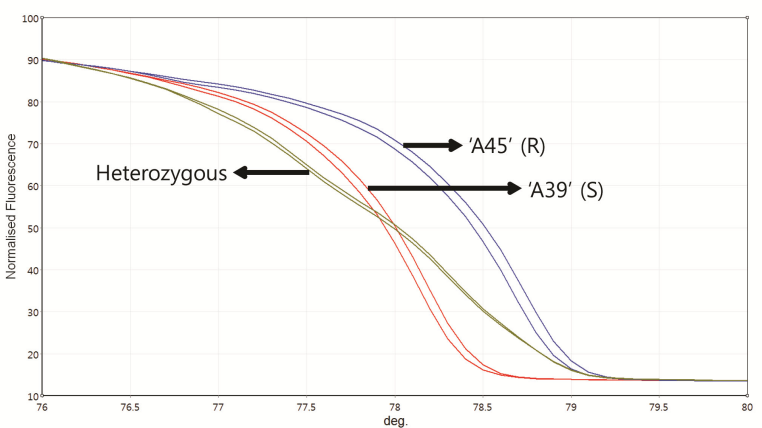

B

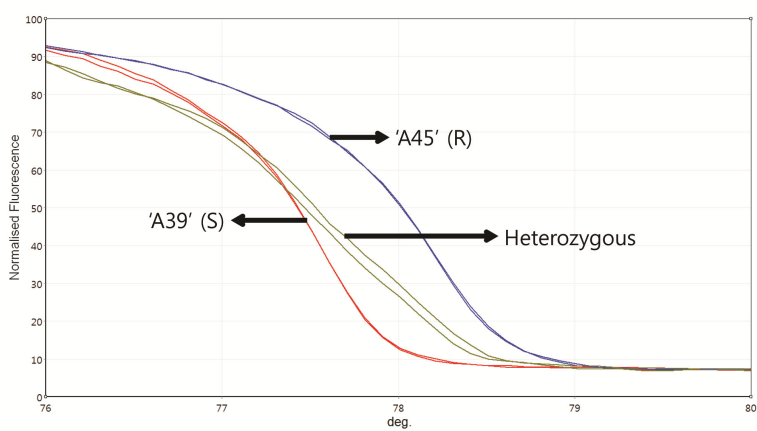

C

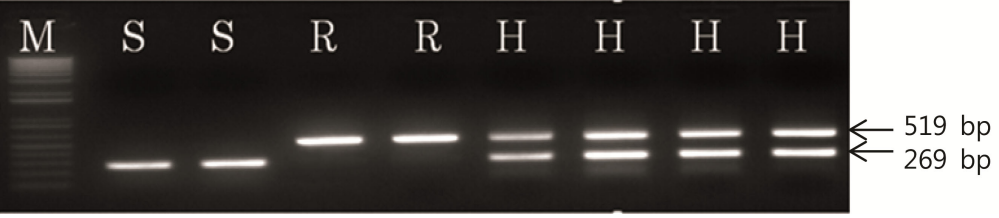

Fig. 3. Normalized HRM curves of Ty3-HRM1 (A) and Ty3-HRM2 (B) and polymerase chain reaction products of SCAR marker Ty3-SCAR1 (C).

M: size marker, S: genotype of susceptible line 'A39', R: genotype of resistant line 'A45', H: genotype of heterozygous $F_{1}$ plants, HRM: high-resolution melting, SCAR: sequence-characterized amplified region. 
Table 3. Co-segregation analysis of Tomato yellow leaf curl virus resistance and genotype of $T y-3$.

\begin{tabular}{|c|c|c|c|c|}
\hline \multirow{2}{*}{ Population } & \multirow{2}{*}{ Genotype } & \multicolumn{2}{|c|}{ Phenotype $^{z)}$} & \multirow{2}{*}{ Total } \\
\hline & & $\mathrm{R}$ & S & \\
\hline \multirow[t]{4}{*}{$\mathrm{BC}_{1} \mathrm{~F}_{1}$} & $\mathrm{R}$ & 0 & 0 & 0 \\
\hline & $\mathrm{H}$ & 41 & $1^{\mathrm{y})}$ & 42 \\
\hline & S & 0 & 33 & 33 \\
\hline & Total & 41 & 34 & 75 \\
\hline \multirow[t]{4}{*}{$\mathrm{F}_{2}$} & $\mathrm{R}$ & 30 & 0 & 30 \\
\hline & $\mathrm{H}$ & 82 & $3^{y)}$ & 85 \\
\hline & $\mathrm{S}$ & 0 & 35 & 35 \\
\hline & Total & 112 & 38 & 150 \\
\hline
\end{tabular}

${ }^{\mathrm{z})} \mathrm{R}$ : resistant, S: susceptible.

${ }^{\mathrm{y})}$ Number of lines did not show the co-segregated results.

except for one $\mathrm{BC}_{1} \mathrm{~F}_{1}$ and three $\mathrm{F}_{2}$ lines with a heterozygous genotype but susceptible results (Table 3). Among these exceptional lines, the one $\mathrm{BC}_{1} \mathrm{~F}_{1}$ line and two of the $\mathrm{F}_{2}$ lines showed susceptibility at disease score level 2 with slight viral symptoms, and the remaining $\mathrm{F}_{2}$ line had a disease score of 3.

\section{Development of SCAR markers}

A SCAR marker was developed using the obtained sequences of the parental plants for Solyc06g051190 (Verlaan et al. 2013). When the sequences of the parents were compared, a 246-bp deletion in the 16th intron was detected in the susceptible line 'A39' (Fig. 2D). To detect the size difference caused by the deletion, a SCAR marker Ty3-SCAR1 was developed (Table 1). This marker generated a 269-bp band in the susceptible line 'A39' and a 519-bp band in the resistant line 'A45' (Fig. 3C). The observation of two bands (of 519-bp and 269-bp) in $\mathrm{F}_{1}$ plants showed that the Ty3-SCAR1 marker could detect the heterozygous genotype. The Ty3-SCAR1 marker showed the same genotype as the two HRM markers for the parental, $\mathrm{F}_{1}, \mathrm{~F}_{2}$, and $\mathrm{BC}_{1} \mathrm{~F}_{1}$ populations, and co-segregated well with the phenotypes except the same four exceptional lines described above.

\section{DISCUSSION}

TYLCV transmitted by the whitefly (B.tabaci) is one of the major challenges facing commercial tomato production worldwide. In Korea, TYLCV incidence was first reported in Tongyoung, Gyoengsangnam-do in 2008, and TYLCV has been transmitted rapidly all over the country (Lee et al. 2015). Therefore, developing TYLCV-resistant cultivars is an urgent breeding goal for seed companies to maintain stable tomato production in Korea. The molecular markers developed in this study will be useful for marker-assisted selection for development of TYLCV-resistant cultivars. Molecular markers play an important role in modern plant breeding, as they confer various advantages such as accuracy of selection and identification of target genes at early stages (de Castro et al. 2007). The previously reported genetic markers linked to the $T y$-3 gene allowed recombination events to occur between the markers and the gene (Ji et al. 2007), making them inappropriate for the marker-assisted selection. In contrast to common molecular markers based on DNA polymorphisms in regions flanking of the gene of interest, gene-based markers markedly enhance the efficiency of MAS (Salgotra et al. 2014). Since the $T y-1 / T y-3$ gene was identified, four gene-based markers have been developed (Jung et al. 2015). Three of them are codominant CAPS markers, and one is a dominant HRM marker. Codominant CAPS markers are applicable to diverse tomato accessions and commercial cultivars, but CAPS markers in general are difficult to use for genotyping of large numbers of samples due to the additional time and effort needed for restriction enzyme digestion and gel electrophoresis.

In this study, we developed codominant HRM markers in different regions of $T y$-3, which overcome the difficulties associated with previously developed markers. HRM can detect SNPs and differentiate genotypes rapidly in one tube without gel electrophoresis, which is useful for large-scale screening of germplasm or cultivars. We also developed an additional gel-based SCAR marker that can detect the susceptible genotype. SCAR markers require more time to use than HRM markers, but produce reproducible results and are less affected by experimental conditions. We developed and tested the markers in populations derived 
from same parent, while another susceptible line 'Heinz 1706' contained the SNPs and a deletion in the same region as the susceptible line we tested. To confirm the applicability of these molecular markers, validation in diverse tomato germplasm will be essential.

In our study, the phenotype of one $\mathrm{BC}_{1} \mathrm{~F}_{1}$ and three $\mathrm{F}_{2}$ plants did not match the genotype revealed using our markers. Even though these lines showed susceptible phenotypes, their disease severity was lower than that of the susceptible parent 'A39'. In addition, when the recombinant plants showed the susceptible phenotype, the marker genotypes of the plants were all heterozygous. This discrepancy may be due to the resistance mechanism of $T y-1 / T y-3$, which mediates virus tolerance rather than immunity. Plants harboring these resistance genes exhibit minor viral replication and systematic infection when they are attacked by TYLCV, although the level does not exceed $10 \%$ of that in susceptible tomato plants (Verlaan et al. 2013). The higher amount of PCR amplicon in some of the heterozygous plants may have led us to score the plants as susceptible. To avoid this error, other detection methods such as ELISA analysis should be tested.

Taken together, our results show that the Agrobacteriummediated TYLCV screening method and the newly developed HRM and SCAR markers described herein will be useful tools for the improvement of TYLCV resistance in tomato.

\section{ACKNOWLEDGEMENTS}

This research was supported by Golden Seed Project (213002-04-4-CG900), Ministry of Agriculture, Food and Rural Affairs (MAFRA), Ministry of Oceans and Fisheries (MOF), Rural Development Administration (RDA) and Korea Forest Service (KFS), Republic of Korea, and a grant (710001-07) from the Vegetable Breeding Research Center through Agriculture, Food and Rural Affairs Research Center Support Program, Ministry of Agriculture, Food and Rural Affairs.

\section{REFERENCES}

Agrama HA, Scott JW. 2006. Quantitative trait loci for Tomato yellow leaf curl virus and tomato mottle virus resistance in tomato. J. Am. Soc. Hortic. Sci. 131: 267-272.

de Castro AP, Blanca JM, Díez MJ, Viñals FN. 2007. Identification of a CAPS marker tightly linked to the tomato yellow leaf curl disease resistance gene Ty-1 in tomato. Eur. J. Plant Pathol. 117: 347-356.

Deng D, McGrath PF, Robinson DJ, Harrison BD. 1994. Detection and differentiation of whitefly-transmitted geminiviruses in plants and vector insects by the polymerase chain reaction with degenerate primers. Ann. Appl. Biol. 125: 327-336.

Doyle JJ, Doyle JL. 1987. A rapid DNA isolation procedure for small quantities of fresh leaf tissue. Phytochem. Bull. 19: 11-15.

Gonzalez-Cabezuelo JM, Capel J, Abad J, Tomás DM, Fernández-Muñoz R, Moriones E, et al. 2012. Genotyping selection for resistance against Tomato yellow leaf curl virus (TYLCV) conferred by Ty- 1 and Ty-3 genes in tomato. Mol. Breed. 30: 1131-1142.

Hilje L, Costa H, Stansly P. 2001. Cultural practices for managing Bemisia tabaci and associated viral diseases. Crop Protect. 20: 801-812.

Horowitz R, Denholm I, Morin S. 2007. Resistance to insecticides in the TYLCV vector, bemisia tabaci, $\mathrm{p}$. 305-325. In: H. Czosnek (ed.). Tomato yellow leaf curl virus Disease. Springer Netherlands, Dordrecht.

Ji Y, Schuster DJ, Scott JW. 2007. Ty-3, a begomovirus resistance locus near the Tomato yellow leaf curl virus resistance locus Ty- 1 on chromosome 6 of tomato. Mol. Breed. 20: 271-284.

Ji Y, Scott JW, Schuster DJ. 2009a. Toward fine mapping of the Tomato yellow leaf curl virus resistance gene Ty-2 on chromosome 11 of tomato. HortScience 44: 614-618.

Ji Y, Scott JW, Schuster DJ, Maxwell DP. 2009b. Molecular mapping of Ty-4, a new Tomato yellow leaf curl virus resistance locus on chromosome 3 of tomato. J. Am. Soc. Hortic. Sci. 134: 281-288.

Jung J, Kim HJ, Lee JM, Oh CS, Lee HJ, Yeam I. 2015. Gene-based molecular marker system for multiple disease resistances in tomato against tomato yellow leaf curl virus, late blight, and verticillium wilt. Euphytica 
205: 599-613.

Lapidot M, Ben-Joseph R, Cohen L, Machbash Z, Levy D. 2006. Development of a scale for evaluation of Tomato yellow leaf curl virus resistance level in tomato plants. Phytopathology 96: 1404-1408.

Lee H, Song W, Kwak HR, Kim JD, Park J, Auh CK, et al. 2010. Phylogenetic analysis and inflow route of Tomato yellow leaf curl virus (TYLCV) and Bemisia tabaci in Korea. Mol. Cells 30: 467-476.

Lee JM, Oh CK, Yeam I. 2015. Molecular markers for selecting diverse disease resistances in tomato breeding programs. Plant Breed. Biotech. 3: 308-322.

Liu JF, Xiao QM, Zhang DY, Tang QJ. 2013. Research progress of Tomato yellow leaf curl virus. Chin. Agric. Sci. Bull. 13: 70-76.

Melzer MJ, Ogata DY, Fukuda SK, Shimabuku R, Borth WB, Sether DM, et al. 2010. First report of Tomato yellow leaf curl virus in Hawaii. Plant Dis. 94: 641.2-641.2.

Naika S, van Lidt de Juede J, Goffau M, Hilmi M, van Dam B. 2005. Cultivation of tomato. Production, processing and marketing. Agromisa Foundation, Wageningen.

Palumbo J, Horowitz A, Prabhaker N. 2001. Insecticidal control and resistance management for Bemisia tabaci.
Crop Prot. 20: 739-765.

Polston JE, Anderson PK. 1997. The emergence of whitefly-transmitted geminiviruses in tomato in the western hemisphere. Plant Dis. 81: 1358-1369.

Rojas M, Kon T, Natwick E, Polston J, Akad F, Gilbertson R. 2007. First report of Tomato yellow leaf curl virus associated with tomato yellow leaf curl disease in California. Plant Dis. 91: 1056.

Salgotra RK, Gupta BB, Stewart CN Jr. 2014. From genomics to functional markers in the era of next-generation sequencing. Biotechnol. Lett. 36: 417-426.

Varma A, Malathi VG. 2003. Emerging geminivirus problems: a serious threat to crop production. Ann. Appl. Biol. 142: 145-164.

Verlaan MG, Hutton SF, Ibrahem RM, Kormelink R, Visser RG, Scott JW, et al. 2013. The Tomato yellow leaf curl virus resistance genes Ty- 1 and Ty- 3 are allelic and code for DFDGD-class RNA-dependent RNA polymerases. PLoS Genet. 9: e1003399.

Zhang H, Gong H, Zhou X. 2009. Molecular characterization and pathogenicity of Tomato yellow leaf curl virus in China. Virus Genes 39: 249-255. 